\title{
Attenuation of airway inflammation by simvastatin and the implications for asthma treatment: is the jury still out?
}

\author{
Jing-Nan Liu, Dong-Hyeon Suh, Eun-Mi Yang, Seung-Ihm Lee, Hae-Sim Park and Yoo Seob Shin
}

\begin{abstract}
Although some studies have explained the immunomodulatory effects of statins, the exact mechanisms and the therapeutic significance of these molecules remain to be elucidated. This study not only evaluated the therapeutic potential and inhibitory mechanism of simvastatin in an ovalbumin (OVA)-specific asthma model in mice but also sought to clarify the future directions indicated by previous studies through a thorough review of the literature. BALB/c mice were sensitized to OVA and then administered three OVA challenges. On each challenge day, $40 \mathrm{mg} \mathrm{kg}^{-1}$ simvastatin was injected before the challenge. The airway responsiveness, inflammatory cell composition, and cytokine levels in bronchoalveolar lavage (BAL) fluid were assessed after the final challenge, and the T cell composition and adhesion molecule expression in lung homogenates were determined. The administration of simvastatin decreased the airway responsiveness, the number of airway inflammatory cells, and the interleukin (IL)-4, IL-5 and IL-13 concentrations in BAL fluid compared with vehicle-treated mice $(P<0.05)$. Histologically, the number of inflammatory cells and mucus-containing goblet cells in lung tissues also decreased in the simvastatin-treated mice. Flow cytometry showed that simvastatin treatment significantly reduced the percentage of pulmonary $\mathrm{CD} 4{ }^{+}$cells and the $\mathrm{CD} 4^{+} / \mathrm{CD}^{+}$ T-cell ratio $(P<0.05)$. Simvastatin treatment also decreased the expression of the vascular cell adhesion molecule 1 and intercellular adhesion molecule 1 proteins, as measured in homogenized lung tissues $(\boldsymbol{P}<0.05)$ and human epithelial cells. The reduction in the $\mathrm{T}$ cell influx as a result of the decreased expression of cell adhesion molecules is one of the mechanisms by which simvastatin attenuates airway responsiveness and allergic inflammation. Rigorous review of the literature together with our findings suggested that simvastatin should be further developed as a potential therapeutic strategy for allergic asthma.

Experimental \& Molecular Medicine (2014) 46, e113; doi:10.1038/emm.2014.55; published online 12 September 2014
\end{abstract}

\section{INTRODUCTION}

Statins are 3-hydroxy-3-methylglutaryl co-enzyme A reductase inhibitors and are frequently used to treat hyperlipidemia and cardiovascular diseases. Statins have also been proposed as novel drugs for treating inflammatory diseases, including asthma, ${ }^{1-7}$ because of their anti-inflammatory and immunomodulatory properties in cardiovascular diseases. ${ }^{8}$ Although these functions of statins have already been investigated in some animal and human studies, ${ }^{2,5,9-18}$ the anti-inflammatory mechanisms of statins and the interrelationships of these mechanisms are far from being completely understood, and some studies have obtained contradictory results.

Asthma is a chronic airway inflammatory disease that is associated with a large influx of inflammatory cells from the systemic circulation into airway tissues. Lymphocytes have a central role in the development of allergic inflammation. ${ }^{19}$
$\mathrm{CD} 4{ }^{+} \mathrm{T}$ cells, especially Th2 cells, are effector cells that have been identified in both bronchoalveolar lavage (BAL) fluid and airway tissues in asthma patients, and the transfer of Th2 cells followed by airway allergen challenge in mice induces airway hyper-responsiveness (AHR) and airway eosinophilia. ${ }^{20,21}$ $\mathrm{CD}^{+}{ }^{+} \mathrm{T}$ cells also act as effector cells in the airway and have an important role in the development of AHR and airway inflammation following allergen challenge. ${ }^{22}$

The inflammatory cell influx in asthma is triggered by endothelial cell adhesion molecules, such as vascular cell adhesion molecule 1 (VCAM-1) and intercellular adhesion molecule 1 (ICAM-1)..$^{23,24}$ The infiltration of inflammatory cells into airways is associated with elevated VCAM-1 expression in endothelial cells, which is enhanced by Th2mediated cytokines. ${ }^{25}$

A variety of mechanisms have been proposed to explain the potent anti-inflammatory and immunomodulatory effects of

Department of Allergy and Clinical Immunology, Ajou University School of Medicine, Suwon, Korea

Correspondence: Professor YS Shin, Department of Allergy and Clinical Immunology, Ajou University School of Medicine, 164 Worldcup-ro, Suwon 443-721, Korea. 
statins. The administration of statins has been shown to suppress inflammation via a reduction in secretory cytokines and chemokines, such as IL-1, IL-6, IL-8, IL-12 and tumor necrosis factor- $\alpha$, in asthma patients, ${ }^{8}$ and the inhibitory effects of simvastatin on mitogen-activated protein kinases, small $G$ proteins and the pro-inflammatory transcription factor nuclear factor $\kappa \mathrm{B}$ have also been observed in a mouse asthma model. ${ }^{2}$ However, the underlying interactions of the different immune cells, including the role of cytokines, remain unclear and there are conflicting reports of these interactions. Therefore, this study sought to thoroughly investigate previous reports, in the light of our findings, to gain insight into the inhibitory mechanisms of statins. We focused on cellular influx in an OVA-specific mouse model of allergic asthma and systemic simvastatin administration.

\section{MATERIALS AND METHODS}

\section{Animals}

Six-week-old, female BALB/c mice weighing $20 \pm 2 \mathrm{~g}$ were purchased from Jackson Laboratory (Bar Harbor, ME, USA). All mice were housed under specific pathogen- and ovalbumin (OVA)-free conditions and maintained on a 12-h light-dark cycle with food and water ad libitum. All experimental animals used in this study were kept under a protocol approved by the Institutional Animal Care and Use Committee of Ajou University (AMC-152 (IACUC-152)).

\section{Sensitization, challenge and simvastatin treatment}

The experimental protocol for allergen sensitization and challenge was modified from previously described methods. ${ }^{26}$ Briefly, BALB/c mice were sensitized intraperitoneally with $10 \mu \mathrm{g}$ OVA (Fisher Scientific, Pittsburgh, PA, USA) emulsified in $1 \mathrm{mg}$ alum (Imject Alum; Pierce, Rockford, IL, USA) on days 0 and 14 . The mice were then subjected to airway allergen challenges by exposure to OVA aerosols ( $1 \%$ in saline) for $20 \mathrm{~min}$ on days 28,29 and 30 with an ultrasonic nebulizer (NE-U22, Omron, Kyoto, Japan). Simvastatin ( $40 \mathrm{mg} \mathrm{kg}^{-1}$; SigmaAldrich, St Louis, MO, USA) was then prepared by dissolving $4 \mathrm{mg}$ simvastatin in $100 \mathrm{ml}$ ethanol and $150 \mathrm{ml}$ of $0.1 \mathrm{~N} \mathrm{NaOH}$ and then incubating this solution at $50{ }^{\circ} \mathrm{C}$ for $2 \mathrm{~h}$. The $\mathrm{pH}$ was adjusted to 7 with $\mathrm{HCl}$, and the total volume was $1 \mathrm{ml}$. The $4 \mathrm{mg} \mathrm{ml}^{-1}$ stock solution was diluted in sterile phosphate-buffered saline. Then, $100 \mu \mathrm{l}$ simvastatin solution was injected intraperitoneally $30 \mathrm{~min}$ before the 1\% OVA challenge on days 28-30. Control mice were given phosphate-buffered saline as sham sensitization. All experiments in our study were repeated three times, and each group of mice consisted of eight or nine animals.

\section{Airway resistance measurements \\ The airway resistance to inhaled methacholine (MCh; Sigma-Aldrich) was measured using the flexiVent System (SCIREQ, Montreal, Quebec, Canada) $48 \mathrm{~h}$ after the last OVA challenge, as previously described. ${ }^{27}$ Briefly, the mice were anesthetized with an intraperitoneal injection of pentobarbital sodium $\left(100 \mathrm{mg} \mathrm{kg}^{-1}\right)$, and then a cannula was inserted via tracheotomy. The mice were connected to a computer-controlled small-animal ventilator and ventilated with a tidal volume of $10 \mathrm{ml} \mathrm{kg}^{-1}$ at a frequency of 150 breaths per min and a positive end-expiratory pressure of $2 \mathrm{~cm} \mathrm{H}_{2} \mathrm{O}$ to achieve a mean lung volume close to that during spontaneous breathing. After the baseline measurement, each mouse was challenged with increasing concentrations $(0,1.56,3.12,6.25$ and}

$12.50 \mathrm{mg} \mathrm{ml}^{-1}$ ) of $\mathrm{MCh}$ aerosol, and the peak airway responses to the inhaled MCh were recorded.

\section{BAL and lung histology}

BAL with $1 \mathrm{ml}$ Hank's balanced salt solution via the tracheal cannula was performed immediately after assessing the AHR. The number of leukocytes was counted with a hemocytometer, and cell differentiation was performed on CytoSpin slides prepared with Wright-Giemsa stain. After BAL, the lungs were fixed in 10\% formalin, embedded in paraffin, and cut into $5-\mu \mathrm{m}$ sections. The numbers of inflammatory and mucus-containing cells were quantified as described previously. ${ }^{28}$ Tissue sections were evaluated using ImageJ (National Institutes of Health, Bethesda, MD, USA). To detect inflammatory cells, sections were stained with hematoxylin and eosin, and the number of inflammatory cells per $\mu \mathrm{m}^{2}$ of perivascular and peribronchial area was determined. In addition, mucus-containing cells were stained with periodic acid-Schiff (PAS) and counterstained with hematoxylin. The number of mucus-containing cells per $\mu \mathrm{m}^{2}$ of basement membrane was determined.

\section{ELISA}

The BAL fluid was centrifuged, and the supernatant was frozen until further analysis. The levels of IL-4, IL-5, IL-13 and interferon- $\gamma$ in the BAL fluid were measured using a sandwich ELISA according to the manufacturer's instructions (eBioscience, San Diego, CA, USA). The lower limits of detection were $3 \mathrm{pg} \mathrm{ml}^{-1}$ for IL-4 and IL-13, $7 \mathrm{pg} \mathrm{ml}^{-1}$ for IL-5 and $13 \mathrm{pg} \mathrm{ml}^{-1}$ for interferon- $\gamma$.

\section{Isolation of lung mononuclear cells and flow cytometry}

Lung mononuclear cells were isolated and purified after collagenase digestion as described previously. ${ }^{29}$ After purification, the lung mononuclear cells were incubated with antibodies and then analyzed by flow cytometry following the manufacturer's instructions. The CD3-FITC, CD8-APC and CD4-PE antibodies were purchased from eBioscience.

\section{In vitro cell culture}

The human bronchoepithelial cell line BEAS-2B (American Type Culture Collection, Manassas, VA, USA) and human umbilical vein endothelial cells (HUVECs; American Type Culture Collection) were placed in six-well plates $\left(2 \times 10^{5}\right.$ cells per well $)$. The BEAS- $2 \mathrm{~B}$ cells were cultured in RPMI-1640, and the HUVECs were cultured in Dulbecco's modified Eagle's medium supplemented with $10 \%$ fetal bovine serum under a $5 \% \mathrm{CO}_{2}$ humidified atmosphere at $37^{\circ} \mathrm{C}$. After reaching confluence, the culture medium was replaced by serum-free medium with different doses of simvastatin $(0.1,1$ and $10 \mu \mathrm{M})$ for $24 \mathrm{~h}$. Then, the cells were stimulated with $5 \mu \mathrm{g} \mathrm{ml}^{-1}$ lipopolysaccharide for $3 \mathrm{~h}$ with or without pre-treatment with different concentrations of simvastatin. Then, the adhesion molecule expression was determined by western blotting.

\section{Western blot analysis}

Lung tissues were homogenized, and lung lysates were prepared in lysis buffer. Cell extracts were prepared from BEAS-2B cells and HUVECs. Then, the protein samples $(25 \mu \mathrm{g})$ were subjected to $10 \%$ SDS-polyacrylamide gel electrophoresis and transferred to nitrocellulose membranes. The membranes were blocked by $5 \%$ fat-free milk and then incubated with antibodies targeting the mouse proteins VCAM-1 (sc8304, 1:1000), ICAM-1 (sc1511, 1:1000) or $\beta$-actin (sc1616, 1:1000; Santa Cruz Biotechnology, CA, USA). 


\section{Data analysis}

The results are presented as the means \pm s.e.m. Data were compared using an unpaired Student's $t$-test or one-way analysis of variance using SPSS 18.0 (SPSS, Chicago, IL, USA). Differences were considered statistically significant if the $P$-value was lower than 0.05 .

\section{RESULTS}

Simvastatin treatment prevents the development of AHR and airway inflammation

To determine the effects of simvastatin treatment on allergen-induced AHR and airway inflammation, mice were treated with simvastatin during the OVA challenge phase. As shown in Figures $1 \mathrm{a}$ and $\mathrm{b}$, vehicle-treated mice showed greater airway responses to $\mathrm{MCh}$, as well as eosinophilia, in BAL fluid following sensitization and challenge with OVA compared with sham-sensitized, OVA-challenged mice. Mice treated with simvastatin developed significantly less airway responsiveness to inhaled MCh and less eosinophilia in BAL fluid than did the vehicle-treated mice $(P<0.01)$.

As shown in Figure 2, simvastatin treatment of sensitized and challenged mice also reduced the levels of IL-4, IL-5 and IL-13 in BAL fluid, but we did not find a significant difference in the interferon- $\gamma$ level compared with that in the vehicletreated mice.

Histopathological analysis of lung tissue sections revealed that the numbers of inflammatory cells, including eosinophils, in the peribronchial and perivascular areas increased in mice after OVA sensitization and challenge compared with sham-sensitized, OVA-challenged mice (Figure 3A). Similarly, the numbers of $\mathrm{PAS}^{+}$mucuscontaining goblet cells increased in the sensitized and challenged mice (Figure 3B). The administration of simvastatin significantly decreased the numbers of inflammatory cells and $\mathrm{PAS}^{+}$mucus-containing goblet cells in lung tissue (Figures $3 \mathrm{~A}$ and $\mathrm{B}$ ).

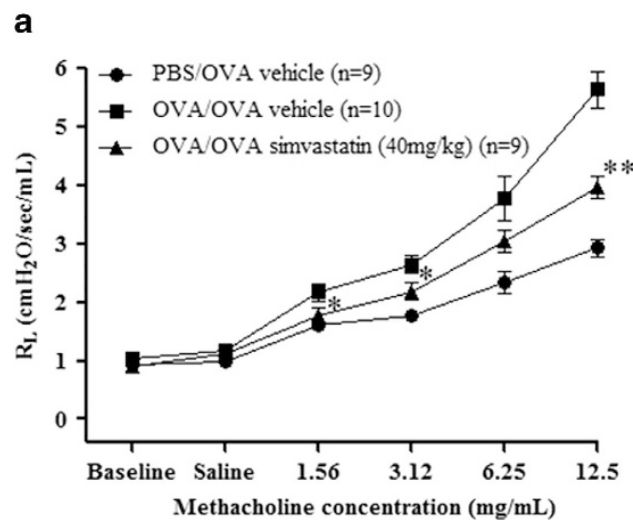

Decrease in $\mathrm{CD}^{+}{ }^{+} \mathrm{T}$-cell number and $\mathrm{CD} 4^{+} / \mathrm{CD}^{+}{ }^{+} \mathrm{T}$-cell ratio in the lungs of sensitized and challenged mice following simvastatin treatment

As $\mathrm{CD}_{4}{ }^{+}$and $\mathrm{CD}^{+}{ }^{+} \mathrm{T}$ cells are potent effector cells in the development of allergic inflammation, we examined their numbers after simvastatin treatment in sensitized and challenged mice. Lungs from OVA-sensitized and OVA-challenged mice receiving either simvastatin or vehicle were excised, and the lung mononuclear cells were purified. The numbers of $\mathrm{CD}^{+}{ }^{+}$and $\mathrm{CD} 8{ }^{+} \mathrm{T}$ cells were determined by flow cytometry. Simvastatin treatment significantly reduced the mean absolute percentage of $\mathrm{CD}^{+}$cells $(46.44 \pm 8.19$ vs $40.19 \pm 7.11$,

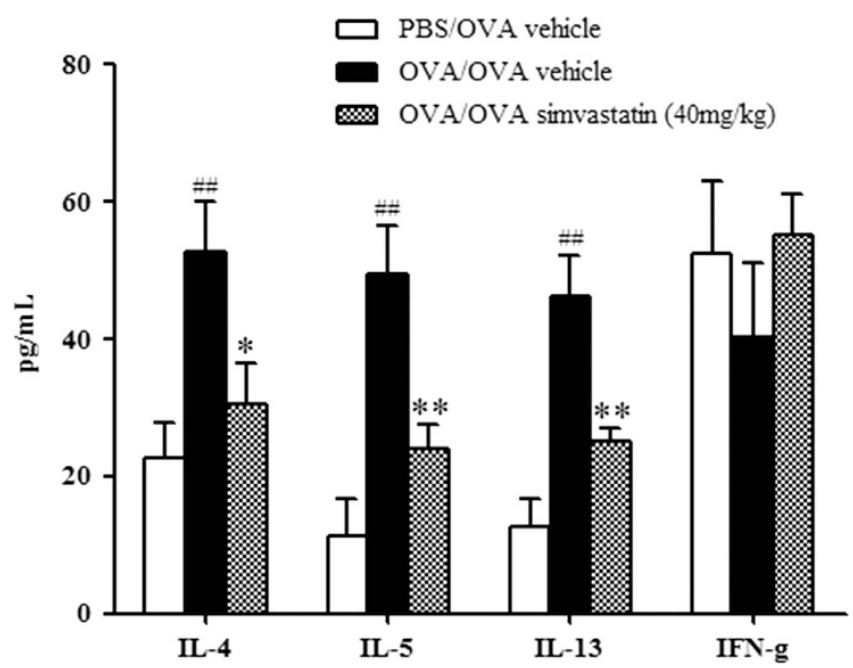

Figure 2 Effect of simvastatin administration on cytokine levels. Interleukin (IL)-4, IL-5, IL-13 and interferon (IFN)- $\gamma$ levels in bronchoalveolar lavage fluid were determined by ELISA. The data are expressed as the mean \pm s.e.m.; $n=9-10$. \#\# $P<0.01$ vs the phosphate-buffered saline (PBS)/ovalbumin (OVA) vehicle group; ${ }^{*} P<0.01$ vs the OVA/OVA vehicle group; ${ }^{*} P<0.05$ vs the OVA/OVA vehicle group.

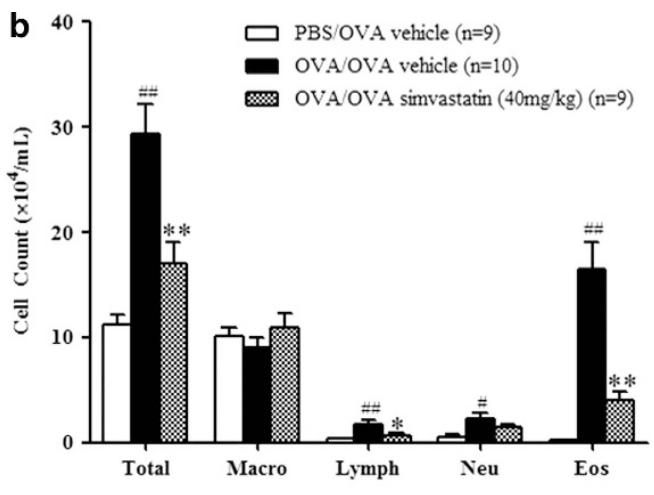

Figure 1 Effect of simvastatin administration on airway responses in an ovalbumin (OVA)-specific asthma model. (a) Changes in lung resistance in response to increasing doses of methacholine $\left(0,1.56,3.12,6.25\right.$ and $12.5 \mathrm{mg} \mathrm{kg}^{-1}$ ) were assessed $48 \mathrm{~h}$ after the final challenge and are expressed as a per cent of the baseline (saline) value. (b) Cell composition in bronchoalveolar lavage fluid. Macro, macrophages; Lympho, lymphocytes; Eos, eosinophils; Neu, neutrophils. Control mice received saline as the vehicle. The data are expressed as the mean \pm s.e.m.; $n=9-10$ per group. ${ }^{\#} P<0.01$ vs the phosphate-buffered saline (PBS)/OVA vehicle group; $P<0.05$ vs the PBS/OVA group; ${ }^{*} P<0.01$ vs the OVA/OVA vehicle group; ${ }^{*} P<0.05$ vs the OVA/OVA group. 
A a

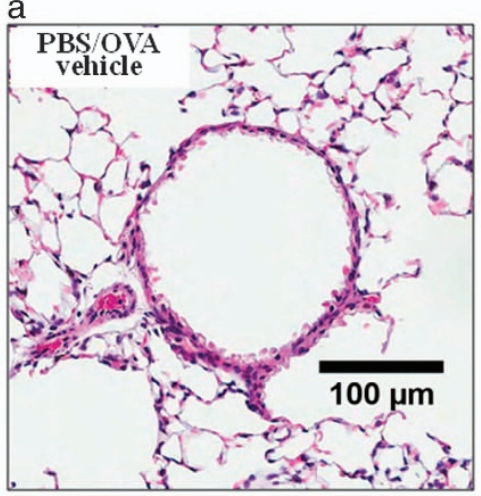

C

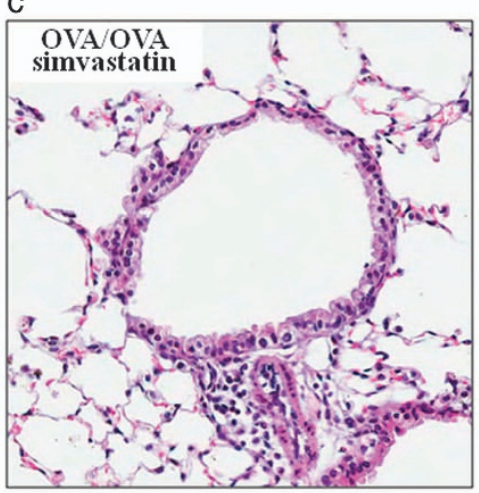

B a

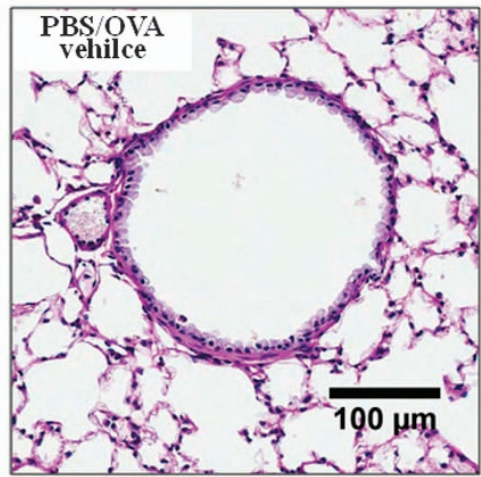

c

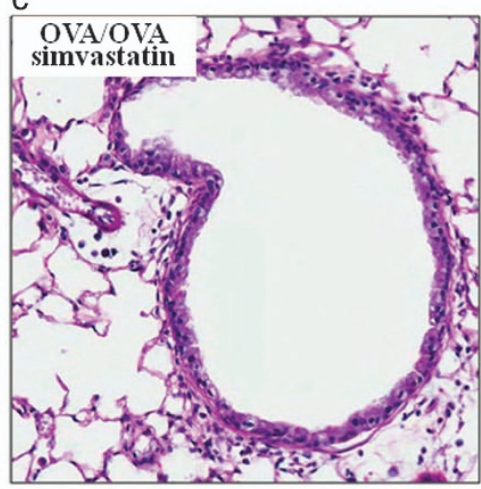

b

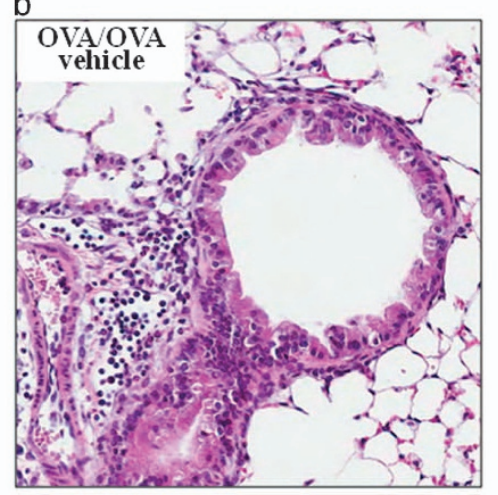

d

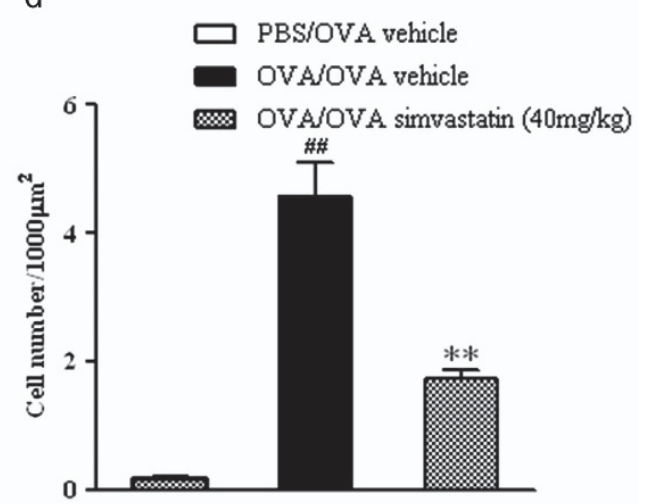

b

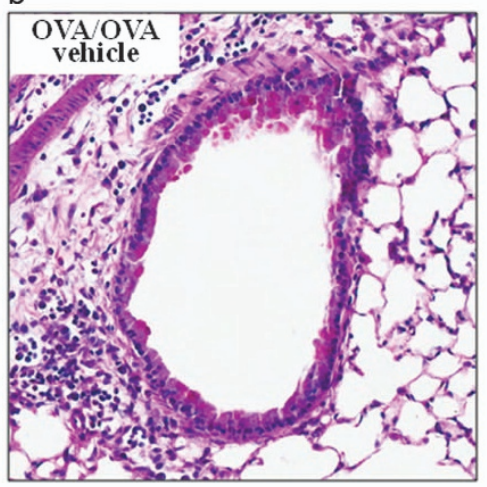

d

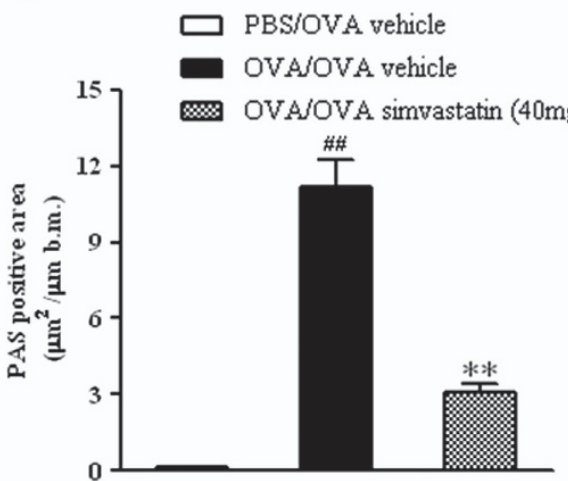

Figure 3 Effect of simvastatin administration on histology. (A) Lung tissue histology with hematoxylin and eosin and (B) periodic acidSchiff (PAS) staining. Inflammatory and PAS ${ }^{+}$cells in lung tissue were quantified as described in the Materials and methods. (a) Mice sensitized and given nebulized phosphate-buffered saline (PBS; negative control); (b) mice sensitized and given nebulized ovalbumin

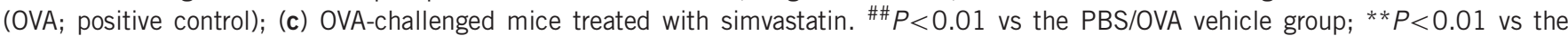
OVA/OVA vehicle group; (d) Numbers of perivascular and peribronchial inflammatory cells $/ 1000 \mu m^{2}$ (Figure 3 Ad); mucus-containing cells stained with PAS were quantitated and expressed as PAS-positive areas/ $\mu \mathrm{m}$ of basement membrane (Figure 3Bd). 
$P<0.05)$ and the $\mathrm{CD}^{+} / \mathrm{CD} 8^{+}$T-cell ratio $(5.48 \pm 0.87$ vs $4.43 \pm 1.31, \quad P<0.05)$, whereas $\mathrm{CD}^{+}$T-cell percentage $(8.51 \pm 1.28$ vs $9.49 \pm 1.97, P>0.05)$ did not significantly differ between simvastatin- and vehicle-treated mice (Table 1).

Decreased adhesion molecule levels following simvastatin treatment in vivo and in vitro

Next, we quantified the levels of adhesion molecules in the lungs of sensitized and challenged mice following simvastatin treatment. The expression of the VCAM-1 and ICAM-1 proteins increased in the lungs of sensitized and challenged mice, whereas the levels were reduced significantly in simvastatin-treated mice (Figures $4 \mathrm{a}$ and $\mathrm{b}$ ).

Experiments with human BEAS-2B cells and HUVECs revealed similar decreases in the expression of VCAM-1 and ICAM-1 after simvastatin treatment (Figures 5A and B).

Table 1 Percentages of CD4 ${ }^{+}$and CD8 ${ }^{+}$T cells in lung homogenates after simvastatin administration

\begin{tabular}{lccc}
\hline T cells & $\begin{array}{c}\text { PBS/OVA } \\
\text { vehicle }\end{array}$ & $\begin{array}{c}\text { OVA/OVA } \\
\text { vehicle }\end{array}$ & $\begin{array}{c}\text { OVA/OVA simvastatin } \\
\left(40 \mathrm{mg} \mathrm{kg}^{-1}\right)\end{array}$ \\
\hline $\mathrm{CD}^{+}(\%)$ & $36.86 \pm 6.38$ & $46.44 \pm 8.19^{\#}$ & $40.19 \pm 7.11^{*}$ \\
$\mathrm{CD}^{+}(\%)$ & $12.60 \pm 3.49$ & $8.51 \pm 1.28^{\#}$ & $9.49 \pm 1.97$ \\
$\mathrm{CD}^{+}{ }^{+}$ & $3.05 \pm 0.69$ & $5.48 \pm 0.87^{\# \#}$ & $4.43 \pm 1.31^{*}$ \\
$\mathrm{CD}^{+}$ & & & \\
\hline
\end{tabular}

Abbreviations: OVA, ovalbumin; PBS, phosphate-buffered saline.

${ }^{\#} P<0.05$, \#\# $P<0.01$ vs the PBS/OVA vehicle ${ }^{*} P<0.05$ vs the OVA/OVA vehicle.
Correlations between $\mathrm{CD}^{+}{ }^{+} \mathrm{T}$-cell numbers and adhesion molecule levels

To investigate the association between $\mathrm{CD}^{+}{ }^{+} \mathrm{T}$-cell numbers and adhesion molecule levels in lung homogenates, a Spearman correlation analysis was conducted. The percentage of $\mathrm{CD}^{+} \mathrm{T}$ cells showed a significant positive correlation with the expression of VCAM-1 $(P=0.013, R=0.645)$ and ICAM-1 $(P=0.036, R=0.563)$ in simvastatin-treated mice (Figures 6a and $b$ ). It should be noted that the percentage values used were the percentage of total cells.

\section{DISCUSSION}

We set out to accomplish two goals in this paper. The first was based on previously published information and sought to clarify in detail the effects of simvastatin on allergen-induced AHR airway inflammation in asthma. The animal studies and clinical trials of statins are summarized in Tables 2 and 3, respectively. The second goal, which was more important, was to focus on the effect of simvastatin on cellular influx in an OVA-specific mouse model of allergic asthma.

Over the past few decades, there has been a huge increase in the prevalence of asthma in all age groups, especially in developed countries, despite the successful introduction of various asthma medications. ${ }^{30}$ Currently, mainstream asthma treatment is focused on anti-inflammatory drugs, as these drugs are the most effective therapeutic agents for many asthma patients. However, the many patients who are still unable to achieve optimal asthma control account for a significant portion of the vast worldwide health-care costs for asthma, ${ }^{31}$ which suggests that the identification of potential
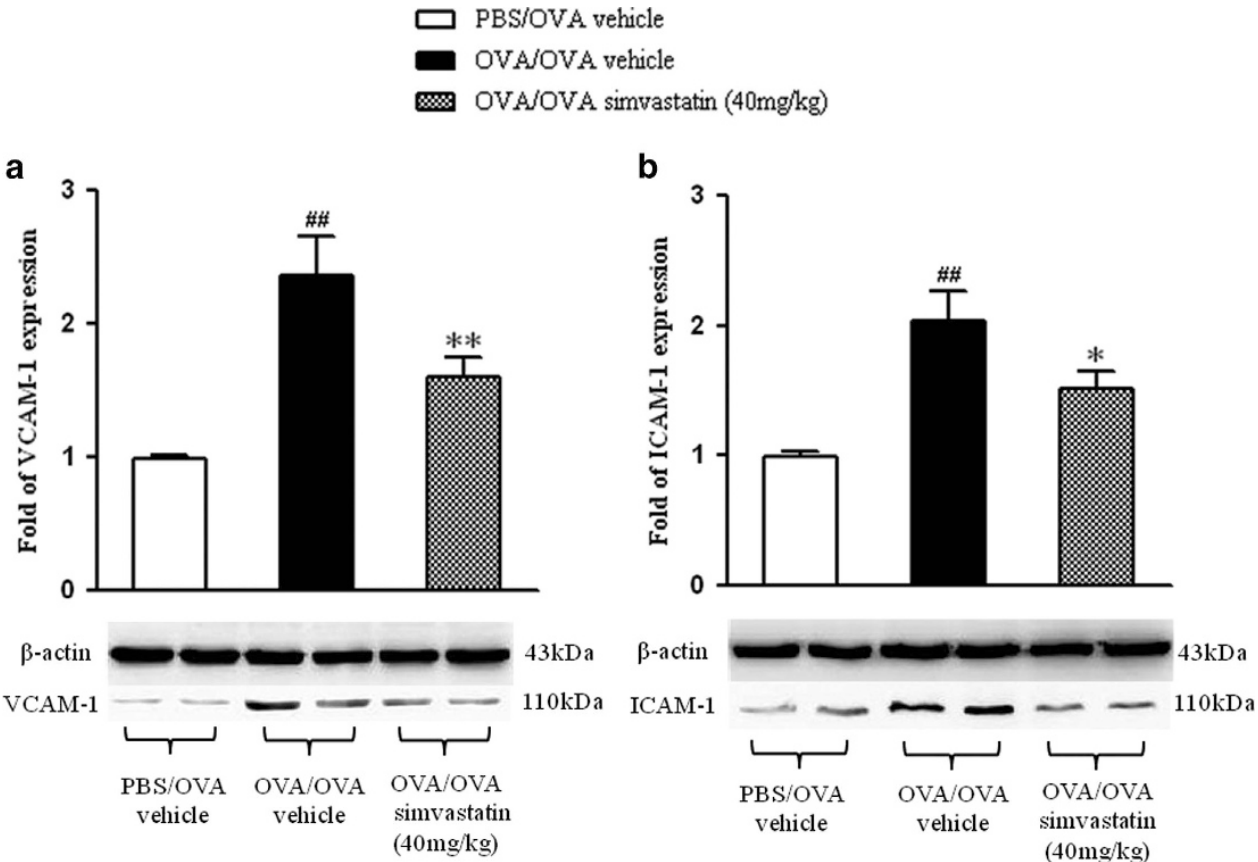

Figure 4 Effects of simvastatin administration on the expression of adhesion molecules in mouse lung homogenates. Vascular cell adhesion molecule 1 (VCAM-1; a) and intercellular adhesion molecule 1 (ICAM-1; b). The data are expressed as the means \pm s.e.m. ${ }^{\# \#} P<0.01$ vs the phosphate-buffered saline (PBS)/ovalbumin (OVA) vehicle group; ${ }^{* *} P<0.01$ vs the OVA/OVA vehicle group; ${ }^{*} P<0.05$ vs the OVA/OVA vehicle group. 
A

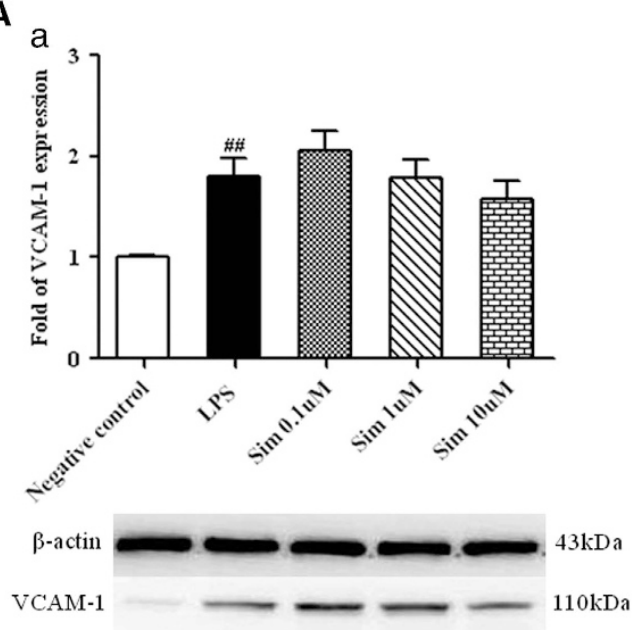

B
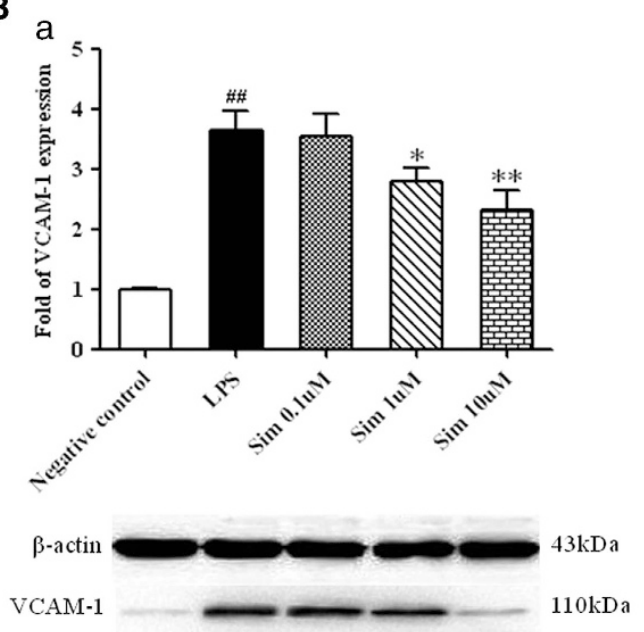
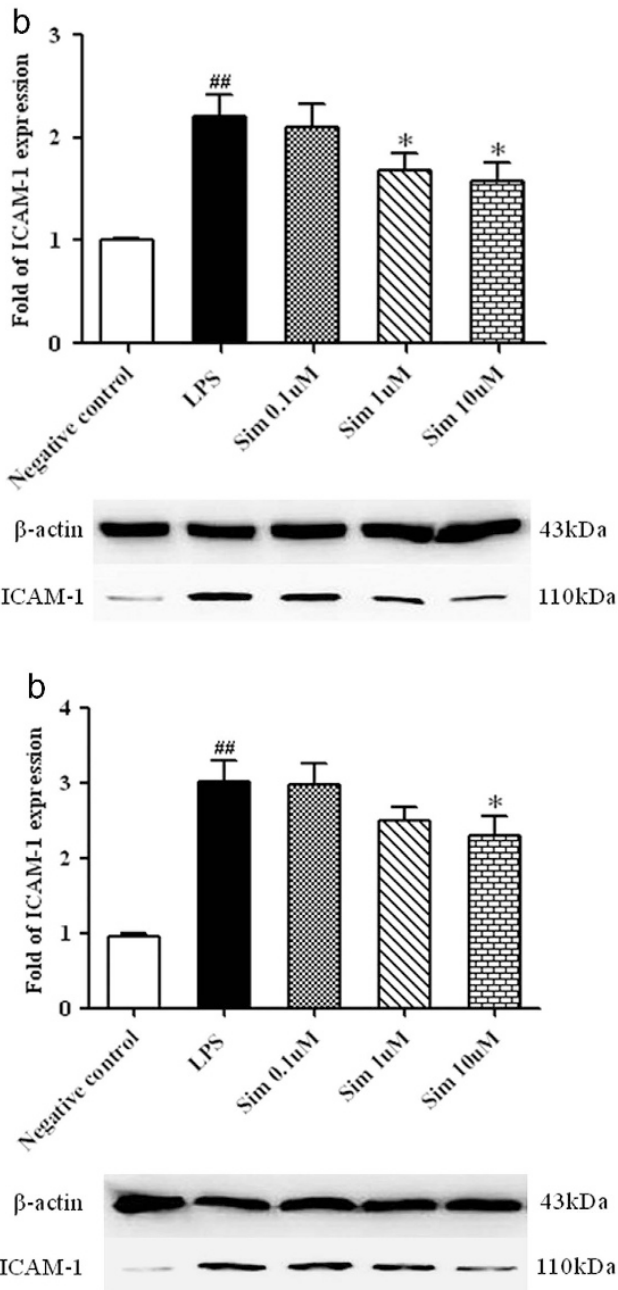

Figure 5 Effects of simvastatin administration on the expression of adhesion molecules in human cell lines. BEAS-2B cells (A) and HUVECs (B). (a) Expression of vascular cell adhesion molecule 1 (VCAM-1); (b) expression of intercellular adhesion molecule 1 (ICAM-1).

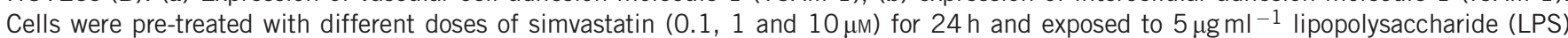
for $6 \mathrm{~h}$ with or without simvastatin pre-treatment. ${ }^{\#} P<0.01$ vs the phosphate-buffered saline/ovalbumin (OVA) vehicle group; ${ }^{*} P<0.01$ vs the OVA/OVA vehicle group; ${ }^{*} P<0.05$ vs the OVA/OVA vehicle group.

targets for therapeutic intervention is an important goal in asthma research.

Because tremendous costs and huge efforts are required to develop a new drug, many existing drugs that are already being used to target one disease are being studied to explore their potential as therapeutics for other diseases. This concept, known as drug repositioning or drug repurposing, has become an increasingly important part of the drug development process. Statins are one such group of drugs. As competitive inhibitors of 3-hydroxy-3-methylglutaryl co-enzyme A reductase, statins have a lipid-lowering capacity and reduce both cardiovascular-related morbidity and mortality in patients with or without coronary disease. ${ }^{32}$ In addition, statins regulate inflammatory processes by interrupting the mevalonate pathway. ${ }^{9}$ For example, statin treatment inhibits the progression of aneurysms associated with degenerative atherosclerosis $^{33}$ and diminishes inflammation and related anemia in end-stage renal disease. ${ }^{34}$ McKay et al. ${ }^{18}$ were among the earliest investigators to suggest the possibility of simvastatin for the treatment of allergic airway disease.

Several studies found that the administration of a statin attenuated AHR, inflammatory cell number and Th2 cytokine levels in mouse models of allergic asthma, ${ }^{2,3,9,10}$ although other studies showed contradictory results. ${ }^{11,12}$ Tschernig et al. ${ }^{12}$ found that the relative and absolute numbers of neutrophils, eosinophils and lymphocytes were only partially reduced after statin treatment. However, they found significantly reduced $\mathrm{CD} 4{ }^{+} \mathrm{T}$-cell numbers in most statin-treated mice, although they did not report significant changes in the asthma-related parameters. These controversial results were repeated in clinical studies. ${ }^{5,7,13,35,36}$ Given the complexity of human studies, various factors might contribute to the controversial results, such as the different characteristics and treatments of the patients. Nevertheless, a recent, large population-based study found that statin exposure was associated with decreased oral corticosteroid dispensing and asthma-related emergency 
a

Simvastatin-treated group

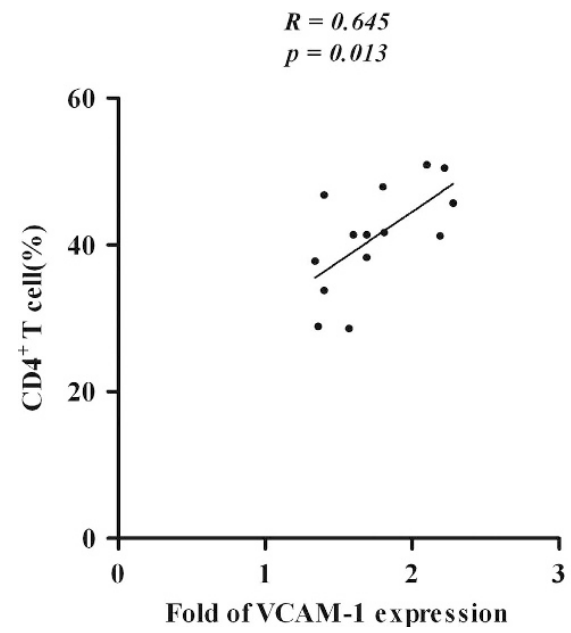

b

Simvastatin-treated group
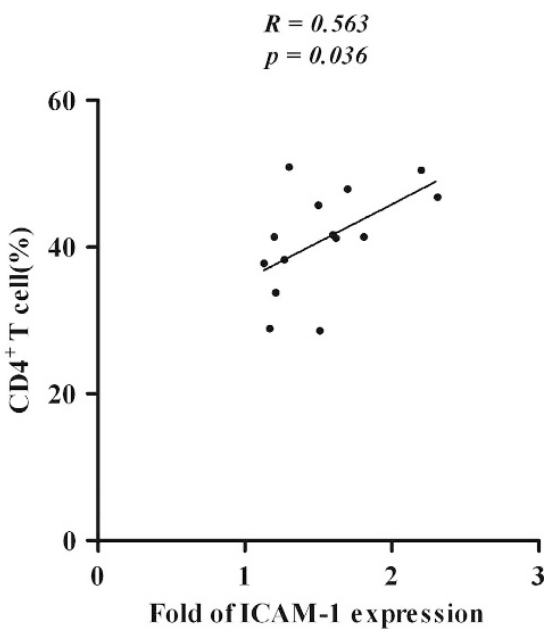

Figure 6 Correlations between CD4 ${ }^{+}$T-cell numbers and adhesion molecule levels. Correlation between CD4 ${ }^{+}$T cells and vascular cell adhesion molecule 1 (VCAM-1; a); correlation between CD4 ${ }^{+}$T cells and intercellular adhesion molecule 1 (ICAM-1; b).

department visits or hospitalizations. ${ }^{35}$ It has been reported by Zeki et al. ${ }^{9}$ that simvastatin may exert its effects through modulation of the mevalonate pathway, whereas $\mathrm{Xu}$ et al. ${ }^{10}$ reported that simvastatin attenuated airway inflammation, remodeling and AHR by inhibiting the RhoA pathway in a dose-dependent manner. Furthermore, the latter proposed the possible administration of simvastatin by inhalation rather than oral administration. This finding is supported by our findings that simvastatin attenuates airway responsiveness and allergic inflammation by reducing the T-cell influx as a result of decreased expression of cell adhesion molecules.

Activated $\mathrm{T}$ cells, especially $\mathrm{CD} 4^{+} \mathrm{T}$ cells, have a pivotal role in the pathophysiology of allergic asthma via the production of cytokines that cause inflammation and promote $\operatorname{IgE}$ production. ${ }^{37,38}$ The recruitment of $\mathrm{CD} 4^{+} \mathrm{T}$ cells has been demonstrated in the lungs and BAL fluid of asthma patients. ${ }^{39-41}$ Another study demonstrated that $\mathrm{CD} 4{ }^{+}$T-cell activation increased the mRNA expression of Th2-type cytokines and the recruitment of eosinophils in BAL after an allergen inhalation challenge in patients with allergic asthma. ${ }^{42}$ In addition, the $\mathrm{CD} 4^{+} / \mathrm{CD} 8{ }^{+}$ratio increased significantly in symptomatic asthma patients compared with healthy controls, and this ratio decreased significantly after treatment. ${ }^{40}$

One of the crucial points of our study is that we found a significant reduction in $\mathrm{CD}^{+}{ }^{+} \mathrm{T}$-cell numbers and in the $\mathrm{CD} 4{ }^{+} / \mathrm{CD} 8{ }^{+}$ratio, with attenuated AHR, airway inflammation and Th2 cytokine levels, in simvastatin-treated mice compared with vehicle-treated mice. The attachment of $\mathrm{T}$ lymphocytes to endothelial cells is a critical step in lymphocyte migration into the surrounding tissue, and the expression of adhesion molecules is the key process of cellular migration. The expression of adhesion molecules such as ICAM-1 and VCAM-1 is regulated by inflammatory cytokines. The pro-inflammatory cytokine IL-1 can upregulate ICAM-1 expression, and Th2 cytokines such as IL-4 and IL-13 enhance VCAM-1 expression, whereas regulatory cytokines cannot modulate either ICAM-1 or VCAM-1 expression. ${ }^{43}$ For example, the expression of ICAM-1 in asthma patients was significantly higher than in healthy controls, and more markedly significant differences were observed in severe asthma attacks. ${ }^{4}$ Thus, methods to reduce ICAM-1 and VCAM-1 expression would be of interest in the development of novel therapeutic methods for asthma. Weitz-Schmidt et al..$^{45}$ has provided evidence showing the anti-inflammatory effect of simvastatin by inhibiting the interaction between LFA1 and ICAM-1 in a T-cell lymphoma cell line.

We also found that the expression of ICAM-1 and VCAM-1 was decreased after simvastatin treatment compared with the vehicle-treated group in both homogenized lung and human cell lines in vitro. Our data clearly show that simvastatin treatment directly reduced the expression of cell adhesion molecules, inhibited the migration of inflammatory cells (especially $\mathrm{CD}^{+}{ }^{+} \mathrm{T}$ cells) from the blood into the airways and sites of inflammation and reduced both the augmentation of cytokines and eosinophil recruitment. In addition, our results showed an expected positive correlation between $\mathrm{CD} 4{ }^{+}$ $\mathrm{T}$-cell numbers and adhesion molecule levels. Therefore, our results support the crucial finding that the downregulation of T-cell-mediated immune responses by simvastatin in asthma occurs via the modulation of cell adhesion molecules, and this new finding opens new horizons for potential further clinical applications. Previous studies lend support to our findings. Tschernig et al. ${ }^{12}$ showed that simvastatin treatment significantly reduced $\mathrm{CD} 4{ }^{+}$T-cell numbers in a rat asthma model. In rheumatoid arthritis patients, the addition of simvastatin to conventional immunosuppressive therapies significantly improved the clinical, biological and immunological parameters by reducing the Th1/Th2 and 
Table 2 Studies about the effects of simvastatin in animal models of asthma and airway inflammation

\begin{tabular}{|c|c|c|c|c|c|c|}
\hline First author & Animals & Treatment & $A H R$ & Airway inflammation & Others molecular changes & Mechanisms \\
\hline $\mathrm{Kim}^{2}$ & $\begin{array}{l}\text { Female } \\
\text { BALB/c } \\
\text { mice }\end{array}$ & i.p. & NA & $\begin{array}{l}\text { Reduced IL-4, IL-5, IL-13, INF- } \alpha \\
\text { protein and mRNA expression in } \\
\text { BAL and lung tissue; reduced } \\
\text { total inflammatory cells and } \\
\text { eosinophils, lymphocytes, macro- } \\
\text { phages, neutrophils in BAL; } \\
\text { reduced inflammatory cell infil- } \\
\text { tration in lung tissue; reduced } \\
\text { goblet cells of airway epithelium }\end{array}$ & $\begin{array}{l}\text { Reduced CD40, CD40L, VCAM-1 } \\
\text { in lung tissue; reduced activities } \\
\text { of MMPs, small G proteins, MAP } \\
\text { kinases and NF-кB }\end{array}$ & $\begin{array}{l}\text { Simvastatin regulates small G } \\
\text { proteins/MAP kinases/NF-kB } \\
\text { activity via CD40 engagement } \\
\text { of lymphocytes }\end{array}$ \\
\hline Tschernig12 & $\begin{array}{l}\text { Female } \\
\text { Fisher } \\
\text { rats }\end{array}$ & i.p., i.t. & NA & $\begin{array}{l}\text { The numbers of neutrophils, } \\
\text { eosinophils and lymphocytes } \\
\text { were only partially reduced by } \\
\text { both i.p. and i.t. administration } \\
\text { routes; reduced CD4 }+ \text { T cells }\end{array}$ & NA & NA \\
\hline Ahmad $^{14}$ & $\begin{array}{l}\text { Female } \\
\text { BALB/c } \\
\text { mice }\end{array}$ & i.p. & $\begin{array}{l}\text { Reduced } \\
\text { AHR }\end{array}$ & $\begin{array}{l}\text { Reduced IL- } 4, \text { IL- } 5 \text { and IL-13 } \\
\text { and increased IL-10 in lung tis- } \\
\text { sue; reduced inflammatory cell } \\
\text { infiltration in lung tissue; reduced } \\
\text { mucous metaplasia of airway } \\
\text { epithelium }\end{array}$ & $\begin{array}{l}\text { Improves no metabolism during } \\
\text { allergic airway inflammation; } \\
\text { reduced ERK1 and ERK2 } \\
\text { phosphorylation }\end{array}$ & $\begin{array}{l}\text { Simvastatin alleviates asth- } \\
\text { matic conditions by modulating } \\
\text { NO metabolism in bronchial } \\
\text { epithelium }\end{array}$ \\
\hline Chen ${ }^{15}$ & $\begin{array}{l}\text { Male } \\
\text { Sprague- } \\
\text { Dawley } \\
\text { rats }\end{array}$ & i.g. & NA & $\begin{array}{l}\text { Reduced total cells and macro- } \\
\text { phages in BAL; reduced TNF- } \alpha \text { in } \\
\text { BAL; attenuated acrolein-induced } \\
\text { goblet cell metaplasia in airway } \\
\text { epithelium }\end{array}$ & $\begin{array}{l}\text { Reduced Ras-GTPase activation; } \\
\text { reduced MUC5AC protein pro- } \\
\text { duction; reduced EGFR/ERK } \\
\text { phosphorylation }\end{array}$ & $\begin{array}{l}\text { Simvastatin blocks ERK activa- } \\
\text { tion mediated by Ras protein } \\
\text { isoprenylation }\end{array}$ \\
\hline $\mathrm{Xu}^{10}$ & $\begin{array}{l}\text { Female } \\
\text { BALB/c } \\
\text { mice }\end{array}$ & $\begin{array}{l}\text { i.t., i.h., } \\
\text { i.g. }\end{array}$ & $\begin{array}{l}\text { Reduced } \\
\text { AHR }\end{array}$ & $\begin{array}{l}\text { Reduced IL-4, IL-5, CCL-11, } \\
\text { INF- } \gamma \text { in BAL; reduced IL-4, IL-5, } \\
\text { CCL-11, INF- } \gamma \text { mRNA in Iung } \\
\text { tissue; reduced total inflamma- } \\
\text { tory cells and eosinophils in BAL; } \\
\text { reduced eosinophil infiltration in } \\
\text { lung tissue; reduced goblet cells } \\
\text { of airway epithelium }\end{array}$ & $\begin{array}{l}\text { Inhibited the upregulation of } \\
\text { RhoA protein expression in lung } \\
\text { tissue }\end{array}$ & $\begin{array}{l}\text { Simvastatin attenuates allergic } \\
\text { airway inflammation in a RhoA- } \\
\text { dependent manner }\end{array}$ \\
\hline
\end{tabular}

Abbreviations: AHR, airway hyper-responsiveness; BAL, bronchoalveolar lavage; EGFR, epidermal growth factor receptor; ERK, extracellular signal-regulated protein kinase; FeNO, fraction of exhaled nitric oxide; i.g., intragastric; i.h., inhalation; i.p., intraperitoneal; i.t., intratracheal; IL, interleukin; INF, interferon; MA, mevalonate; MAP, mitogen-activated protein; MMP, matrix metalloproteinase; NA: not available; NF- $\mathrm{B}$, nuclear factor $\kappa \mathrm{B}$; TGF, transforming growth factor; TNF, tumor necrosis factor; VCAM, vascular cell adhesion molecule. 
Table 3 Clinical trials that investigated the effects of simvastatin in asthma patients

\begin{tabular}{|c|c|c|c|c|c|c|c|}
\hline First author & Patients & Study design & $\begin{array}{l}\text { Sample } \\
\text { (trial/ } \\
\text { control) }\end{array}$ & $\begin{array}{l}\text { Treatment } \\
\text { group }\end{array}$ & $\begin{array}{l}\text { Dose, } \\
\text { duration }\end{array}$ & $\begin{array}{l}\text { Results (simvastatin group } \\
\text { compared with the control } \\
\text { group) }\end{array}$ & Mechanisms or conclusions \\
\hline Maneechotesuwan 5 & $\begin{array}{l}\text { Mild } \\
\text { asthma }\end{array}$ & $\begin{array}{l}\text { Randomized } \\
\text { controlled } \\
\text { trials }\end{array}$ & $\begin{array}{l}47(25 / \\
22)\end{array}$ & $\begin{array}{l}\text { Simvastatin } \\
\text { vs placebo }\end{array}$ & $\begin{array}{l}10 \text { mg per } \\
\text { day, } 8 \text { weeks }\end{array}$ & $\begin{array}{l}\text { Reduced sputum eosinophil } \\
\text { percentages; no significant } \\
\text { change in lung function }\end{array}$ & $\begin{array}{l}\text { Simvastatin enhanced corti- } \\
\text { costeroid-activated, non-cano- } \\
\text { nical NF-кB-dependent } \\
\text { induction of indoleamine } 2 \text {, } \\
\text { 3-dioxygenase }\end{array}$ \\
\hline Menzies $^{6}$ & $\begin{array}{l}\text { Mild to } \\
\text { moderate } \\
\text { asthma }\end{array}$ & $\begin{array}{l}\text { Randomized } \\
\text { controlled } \\
\text { trials }\end{array}$ & $\begin{array}{l}16(16 / \\
16)\end{array}$ & $\begin{array}{l}\text { Simvastatin } \\
\text { vs placebo }\end{array}$ & $\begin{array}{l}20 \mathrm{mg} \text { per } \\
\text { day, } 40 \mathrm{mg} \\
\text { per day, } 4 \\
\text { weeks }\end{array}$ & $\begin{array}{l}\text { No difference between sim- } \\
\text { vastatin and placebo on sys- } \\
\text { temic inflammation markers } \\
\text { (CRP, ECP, absolute peripheral } \\
\text { eosinophil count), lung volume } \\
\text { or airway resistance }\end{array}$ & $\begin{array}{l}\text { There is no evidence to sug- } \\
\text { gest simvastatin has anti- } \\
\text { inflammatory activity in } \\
\text { patients with asthma }\end{array}$ \\
\hline Cowan $^{17}$ & Asthma & $\begin{array}{l}\text { Randomized } \\
\text { controlled } \\
\text { trials }\end{array}$ & 43 (NA) & $\begin{array}{l}\text { Simvastatin } \\
\text { vs placebo }\end{array}$ & $\begin{array}{l}40 \text { mg per } \\
\text { day, } 4 \text { weeks }\end{array}$ & $\begin{array}{l}\text { No significant difference in the } \\
\text { 'minimum' inhaled corticos- } \\
\text { teroid dose requirement; } \\
\text { higher FEV1 and lower sputum } \\
\text { eosinophils }\end{array}$ & $\begin{array}{l}\text { Simvastatin does not have } \\
\text { steroid-sparing effects and is } \\
\text { associated with minor } \\
\text { improvements in symptoms } \\
\text { and lung function and with a } \\
\text { reduction in sputum } \\
\text { eosinophils }\end{array}$ \\
\hline Ostroukhova 7 & Asthma & $\begin{array}{l}\text { Retrospective } \\
\text { study }\end{array}$ & $\begin{array}{l}50(24 / \\
26)\end{array}$ & $\begin{array}{l}\text { Statin } \\
\text { exposed vs } \\
\text { statin } \\
\text { unexposed }\end{array}$ & NA, 2 years & $\begin{array}{l}\text { Statin treatment group showed } \\
\text { worse FEV1; more frequent } \\
\text { office visits for acute asthma }\end{array}$ & $\begin{array}{l}\text { Patients with asthma who } \\
\text { received statins had a worse } \\
\text { clinical course than controls }\end{array}$ \\
\hline Huang ${ }^{1}$ & Asthma & $\begin{array}{l}\text { Retrospective } \\
\text { study }\end{array}$ & $\begin{array}{l}11808 \\
(3965 / \\
7843)\end{array}$ & $\begin{array}{l}\text { Statin } \\
\text { exposed vs } \\
\text { statin } \\
\text { unexposed }\end{array}$ & $\begin{array}{l}N A \\
4.66 \pm 2.32 \\
\text { years }\end{array}$ & $\begin{array}{l}\text { Statin use was independently } \\
\text { associated with a decreased } \\
\text { risk of hospitalization for } \\
\text { asthma }\end{array}$ & $\begin{array}{l}\text { Statin use was associated with } \\
\text { reduced hospitalization for } \\
\text { asthma attack, suggesting } \\
\text { possible applications of statin } \\
\text { in patients with asthma }\end{array}$ \\
\hline Lokhandwala 4 & Asthma & $\begin{array}{l}\text { Retrospective } \\
\text { study }\end{array}$ & $\begin{array}{l}1437 \\
(479 / \\
958)\end{array}$ & $\begin{array}{l}\text { Statin } \\
\text { exposed vs } \\
\text { statin } \\
\text { unexposed }\end{array}$ & NA, 1 year & $\begin{array}{l}\text { The odds of asthma-related } \\
\text { hospitalization and/or emer- } \\
\text { gency room visits were almost } \\
\text { half the odds for patients not } \\
\text { on statins }\end{array}$ & $\begin{array}{l}\text { Statins have beneficial effects } \\
\text { in preventing asthma } \\
\text { exacerbations }\end{array}$ \\
\hline $\mathrm{Tse}^{35}$ & Asthma & $\begin{array}{l}\text { Retrospective } \\
\text { study }\end{array}$ & $\begin{array}{l}16696 \\
(8348 / \\
8348)\end{array}$ & $\begin{array}{l}\text { Statin } \\
\text { exposed vs } \\
\text { statin } \\
\text { unexposed }\end{array}$ & NA, 3 years & $\begin{array}{l}\text { Statin exposure was associated } \\
\text { with decreased odds of having } \\
\text { asthma-related emergency } \\
\text { department visits and two or } \\
\text { more oral corticosteroid dis- } \\
\text { pensings; there were no differ- } \\
\text { ences in asthma-related } \\
\text { hospitalizations }\end{array}$ & $\begin{array}{l}\text { Statin exposure was associated } \\
\text { with decreased odds of } \\
\text { asthma-related emergency } \\
\text { department visits and oral } \\
\text { corticosteroid dispensings }\end{array}$ \\
\hline Zeki36 & $\begin{array}{l}\text { Severe } \\
\text { asthma }\end{array}$ & $\begin{array}{l}\text { Retrospective } \\
\text { study }\end{array}$ & $\begin{array}{l}165 \\
(31 / \\
134)\end{array}$ & $\begin{array}{l}\text { Statin } \\
\text { exposed vs } \\
\text { statin } \\
\text { unexposed }\end{array}$ & NA, 2 years & $\begin{array}{l}\text { Statin users had better asthma } \\
\text { symptom control compared } \\
\text { with non-users; there were no } \\
\text { significant differences in lung } \\
\text { function, corticosteroid, res- } \\
\text { cue bronchodilator use or per- } \\
\text { ipheral eosinophilia }\end{array}$ & $\begin{array}{l}\text { Patients with severe asthma } \\
\text { could potentially benefit from } \\
\text { added statin treatment }\end{array}$ \\
\hline
\end{tabular}

Abbreviations: CRP, c-reactive protein; ECP, serum eosinophil cationic protein; FEV1, forced expiratory volume in one second; NA, not available; NF-кB, nuclear factor $\kappa \mathrm{B}$. 
CD4/CD8 ratios. ${ }^{46}$ Another study suggested that one of the mechanisms by which simvastatin reduces inflammation might be by reducing the expression of adhesion molecules in circulating monocytes, as shown in hypercholesterolemic patients. $^{47}$

Although many experimental and clinical studies have indicated the effectiveness of statins in the treatment of allergic asthma, there are still many controversies, suggesting that there are inter-individual differences in responses, for which genetic differences may be a contributory factor. Therefore, future studies could be designed to identify the genetic changes in specific targets.

To the best of our knowledge, this is the first study to evaluate the effects of simvastatin on $\mathrm{CD} 4{ }^{+}$and $\mathrm{CD} 8{ }^{+}$ $\mathrm{T}$ cells together with the association of simvastatin with adhesion molecules in asthma. However, one limitation of this study was, as in many other experimental studies, that the dose of simvastatin that was administered ( $40 \mathrm{mg} \mathrm{kg}^{-1}$ ) was high compared with the routinely prescribed clinical dose. Further studies are needed to elucidate the detailed interactions between adhesion molecules and $\mathrm{T}$ cells and the possible adverse reactions if simvastatin is administered at high doses in humans. In addition, thorough investigations of other statins and their interactions are also necessary.

Overall, our results provide compelling evidence showing that a reduction in $\mathrm{T}$-cell influx as a result of decreased expression of cell adhesion molecules is one of the mechanisms by which simvastatin attenuates airway responsiveness and allergic inflammation; therefore, taking into account the effects on $\mathrm{CD}^{+}{ }^{+}$and $\mathrm{CD} 8{ }^{+} \mathrm{T}$ cells, statins should be considered novel therapeutic targets in the future treatment of asthma in humans. Because there is a paucity of understanding concerning the basis for variability in human responses, it is necessary to meticulously determine the effect of statins in clinical trials before they can be adopted clinically.

\section{CONFLICT OF INTEREST}

The authors declare no conflict of interest.

\section{ACKNOWLEDGEMENTS}

This study was supported by the Korea Science and Engineering Foundation (KOSEF) grant by the Korean government (MEST, 2013003341). The authors are indebted to J Patrick Barron, Professor Emeritus, Tokyo Medical University, and Adjunct Professor, Seoul National University Bundang Hospital, for his pro bono editing of this manuscript.

1 Huang CC, Chan WL, Chen YC, Chen TJ, Chou KT, Lin SJ et al. Statin use in patients with asthma: a nationwide population-based study. Eur J Clin Invest 2011; 41: 507-512.

2 Kim DY, Ryu SY, Lim JE, Lee YS, Ro JY. Anti-inflammatory mechanism of simvastatin in mouse allergic asthma model. Eur J Pharmacol 2007; 557: 76-86.
3 Samson KT, Minoguchi K, Tanaka A, Oda N, Yokoe T, Yamamoto Y et al. Inhibitory effects of fluvastatin on cytokine and chemokine production by peripheral blood mononuclear cells in patients with allergic asthma. Clin Exp Allergy 2006; 36: 475-482.

4 Lokhandwala T, West-Strum D, Banahan BF, Bentley JP, Yang Y. Do statins improve outcomes in patients with asthma on inhaled corticosteroid therapy? A retrospective cohort analysis. BMJ Open 2012; 2: e001279.

5 Maneechotesuwan K, Ekjiratrakul W, Kasetsinsombat K, Wongkajornsilp A, Barnes PJ. Statins enhance the anti-inflammatory effects of inhaled corticosteroids in asthmatic patients through increased induction of indoleamine 2, 3-dioxygenase. J Allergy Clin Immunol 2010; 126: 754-762.

6 Menzies D, Nair A, Meldrum KT, Fleming D, Barnes M, Lipworth BJ. Simvastatin does not exhibit therapeutic anti-inflammatory effects in asthma. J Allergy Clin Immunol 2007; 119: 328-335.

7 Ostroukhova M, Kouides RW, Friedman E. The effect of statin therapy on allergic patients with asthma. Ann Allergy Asthma Immunol 2009; 103: 463-468.

8 Jain MK, Ridker PM. Anti-inflammatory effects of statins: clinical evidence and basic mechanisms. Nat Rev Drug Discov 2005; 4: 977-987.

9 Zeki AA, Franzi L, Last J, Kenyon NJ. Simvastatin inhibits airway hyperreactivity: implications for the mevalonate pathway and beyond. Am $J$ Respir Crit Care Med 2009; 180: 731-740.

10 Xu L, Dong XW, Shen LL, Li FF, Jiang JX, Cao R et al. Simvastatin delivery via inhalation attenuates airway inflammation in a murine model of asthma. Int Immunopharmacol 2012; 12: 556-564.

11 Chiba Y, Sato S, Misawa M. Lovastatin inhibits antigen-induced airway eosinophilia without affecting the production of inflammatory mediators in mice. Inflamm Res 2009; 58: 363-369.

12 Tschernig T, Baumer W, Pabst R. Controversial data on simvastatin in asthma: What about the rat model? J Asthma Allergy 2010; 3: 57-63.

13 Moini A, Azimi G, Farivar A. Evaluation of atorvastatin for the treatment of patients with asthma: a double-blind randomized clinical trial. Allergy Asthma Immunol Res 2012; 4: 290-294.

14 Ahmad T, Mabalirajan U, Sharma A, Aich J, Makhija L, Ghosh B et al. Simvastatin improves epithelial dysfunction and airway hyperresponsiveness: from asymmetric dimethyl-arginine to asthma. Am J Respir Cell Mol Biol 2011; 44: 531-539.

15 Chen YJ, Chen P, Wang HX, Wang T, Chen L, Wang X et al. Simvastatin attenuates acrolein-induced mucin production in rats: involvement of the Ras/extracellular signal-regulated kinase pathway. Int Immunopharmacol 2010; 10: 685-693.

16 Zeki AA, Bratt JM, Rabowsky M, Last JA, Kenyon NJ. Simvastatin inhibits goblet cell hyperplasia and lung arginase in a mouse model of allergic asthma: a novel treatment for airway remodeling? Trans/ Res 2010; 156: 335-349.

17 Cowan DC, Cowan JO, Palmay R, Williamson A, Taylor DR. Simvastatin in the treatment of asthma: lack of steroid-sparing effect. Thorax 2010; 65 891-896.

18 McKay A, Leung BP, Mclnnes IB, Thomson NC, Liew FY. A novel anti-inflammatory role of simvastatin in a murine model of allergic asthma. J Immunol 2004; 172: 2903-2908.

19 Barnes PJ, Chung KF, Page CP. Inflammatory mediators of asthma: an update. Pharmacol Rev 1998; 50: 515-596.

20 Cohn L, Homer RJ, Marinov A, Rankin J, Bottomly K. Induction of airway mucus production By Thelper 2 (Th2) cells: a critical role for interleukin 4 in cell recruitment but not mucus production. J Exp Med 1997; 186: 1737-1747.

21 Cohn L, Tepper JS, Bottomly K. IL-4-independent induction of airway hyperresponsiveness by Th2, but not Th1, cells. J Immunol 1998; 161: 3813-3816.

22 Saetta M, Turato G. Airway pathology in asthma. Eur Respir J Supp/ 2001 34: $18 \mathrm{~s}-23 \mathrm{~s}$

23 Hasegawa A, Hayashi K, Kishimoto H, Yang M, Tofukuji S, Suzuki K et al. Color-coded real-time cellular imaging of lung T-lymphocyte accumulation and focus formation in a mouse asthma model. J Allergy Clin Immunol 2010; 125: 461-468.

24 Woodside DG, Vanderslice P. Cell adhesion antagonists: therapeutic potential in asthma and chronic obstructive pulmonary disease. BioDrugs 2008; 22: 85-100.

25 Wills-Karp M, Karp CL. Biomedicine. Eosinophils in asthma: remodeling a tangled tale. Science 2004; 305: 1726-1729. 
26 Takeda K, Miyahara N, Kodama T, Taube C, Balhorn A, Dakhama A et al. S-carboxymethylcysteine normalises airway responsiveness in sensitised and challenged mice. Eur Respir J 2005; 26: 577-585.

27 Tarkowski M, Vanoirbeek JA, Vanhooren HM, De Vooght V, Mercier CM, Ceuppens $\mathrm{J}$ et al. Immunological determinants of ventilatory changes induced in mice by dermal sensitization and respiratory challenge with toluene diisocyanate. Am J Physiol Lung Cell Mol Physiol 2007; 292: L207-L214.

28 Tomkinson A, Cieslewicz G, Duez C, Larson KA, Lee JJ, Gelfand EW. Temporal association between airway hyperresponsiveness and airway eosinophilia in ovalbumin-sensitized mice. Am J Respir Crit Care Med 2001; 163: 721-730.

29 Shin YS, Takeda K, Shiraishi Y, Jia Y, Wang M, Jackson L et al. Inhibition of Pim1 kinase activation attenuates allergen-induced airway hyperresponsiveness and inflammation. Am J Respir Cell Mol Biol 2012 ; 46: 488-497.

30 Wong GW, Leung TF, Ko FW. Changing prevalence of allergic diseases in the Asia-pacific region. Allergy Asthma Immunol Res 2013; 5: 251-257.

31 Olaguibel JM, Quirce S, Julia B, Fernandez C, Fortuna AM, Molina J et al. Measurement of asthma control according to Global Initiative for Asthma guidelines: a comparison with the Asthma Control Questionnaire. Respir Res 2012; 13: 50.

32 Kwak B, Mulhaupt F, Myit S, Mach F. Statins as a newly recognized type of immunomodulator. Nat Med 2000; 6: 1399-1402.

33 Shiraya S, Miyake T, Aoki M, Yoshikazu F, Ohgi S, Nishimura M et al. Inhibition of development of experimental aortic abdominal aneurysm in rat model by atorvastatin through inhibition of macrophage migration. Atherosclerosis 2009; 202: 34-40.

34 Koc M, Dogan C, Arinsoy T, Tonbul Z, Ayli D, Cirit M et al. Statin use is associated with lower inflammation and erythropoietin responsiveness index in hemodialysis patients. Hemodial Int 2011; 15: 366-373.

35 Tse SM, Li L, Butler MG, Fung V, Kharbanda EO, Larkin EK et al. Statin exposure is associated with decreased asthma-related emergency department visits and oral corticosteroid use. Am J Respir Crit Care Med 2013; 188: $1076-1082$

36 Zeki AA, Oldham J, Wilson M, Fortenko O, Goyal V, Last M et al. Statin use and asthma control in patients with severe asthma. BMJ Open 2013; 3: e003314.

37 Djukanovic R, Roche WR, Wilson JW, Beasley CR, Twentyman OP, Howarth RH et al. Mucosal inflammation in asthma. Am Rev Respir Dis 1990; 142: 434-457.

38 Bochner BS, Undem BJ, Lichtenstein LM. Immunological aspects of allergic asthma. Annu Rev Immunol 1994; 12: 295-335.

39 Yurovsky VV, Weersink EJ, Meltzer SS, Moore WC, Postma DS, Bleecker ER et al. T-Cell repertoire in the blood and lungs of atopic asthmatics before and after ragweed challenge. Am J Respir Cell Mol Biol 1998; 18: 370-383.

40 Lee SY, Kim SJ, Kwon SS, Kim YK, Kim KH, Moon HS et al. Distribution and cytokine production of CD4 and CD8 T-lymphocyte subsets in patients with acute asthma attacks. Ann Allergy Asthma Immunol 2001; 86: 659-664.

41 Liu MC, Proud D, Lichtenstein LM, Hubbard WC, Bochner BS, Stealey BA et al. Effects of prednisone on the cellular responses and release of cytokines and mediators after segmental allergen challenge of asthmatic subjects. J Allergy Clin Immunol 2001; 108: 29-38.

42 Robinson D, Hamid Q, Bentley A, Ying S, Kay AB, Durham SR. Activation of CD4 + T cells, increased TH2-type cytokine mRNA expression, and eosinophil recruitment in bronchoalveolar lavage after allergen inhalation challenge in patients with atopic asthma. J Allergy Clin Immunol 1993; 92: 313-324.

43 Hosokawa Y, Hosokawa I, Ozaki K, Nakae H, Matsuo T. Cytokines differentially regulate ICAM-1 and VCAM-1 expression on human gingival fibroblasts. Clin Exp Immunol 2006; 144: 494-502.

44 Bijanzadeh M, Ramachandra NB, Mahesh PA, Savitha MR, Vijayakumar GS, Kumar $\mathrm{P}$ et al. Soluble intercellular adhesion molecule-1 and E-selectin in patients with asthma exacerbation. Lung 2009; 187: 315-320.

45 Weitz-Schmidt G, Welzenbach K, Brinkmann V, Kamata T, Kallen J, Bruns $\mathrm{C}$ et al. Statins selectively inhibit leukocyte function antigen-1 by binding to a novel regulatory integrin site. Nat Med 2001; 7: 687-692.

46 Kanda H, Yokota K, Kohno C, Sawada T, Sato K, Yamaguchi M et al. Effects of low-dosage simvastatin on rheumatoid arthritis through reduction of Th1/Th2 and CD4/CD8 ratios. Mod Rheumatol 2007; 17: 364-368.

47 Rezaie-Majd A, Prager GW, Bucek RA, Schernthaner GH, Maca T, Kress HG et al. Simvastatin reduces the expression of adhesion molecules in circulating monocytes from hypercholesterolemic patients. Arterioscler Thromb Vasc Biol 2003; 23: 397-403.

This work is licensed under a Creative Commons Attribution-NonCommercial-NoDerivs 3.0 Un-
ported License. The images or other third party material in this article are included in the article's Creative Commons license, unless indicated otherwise in the credit line; if the material is not included under the Creative Commons license, users will need to obtain permission from the license holder to reproduce the material. To view a copy of this license, visit http://creativecommons.org/licenses/by-nc-nd/3.0/ 